\title{
ADGRE5 wt Allele
}

National Cancer Institute

\section{Source}

National Cancer Institute. ADGRE5 wt Allele. NCI Thesaurus. Code C51136.

Human ADGRE5 wild-type allele is located in the vicinity of 19p13.12 and is approximately $28 \mathrm{~kb}$ in length. This allele, which encodes CD97 antigen immunoprotein, is involved in both cell adhesion and signaling processes early after leukocyte activation. 